\title{
Refinement effect of RE in light weight Mg-Li-Al alloys
}

\author{
Mariusz Król ${ }^{1}\left[\right.$ D $\cdot$ Marcin Staszuk $^{1} \cdot$ Tomasz Mikuszewski $^{2} \cdot$ Dariusz Kuc $^{3}$
}

Received: 27 December 2017 / Accepted: 7 April 2018/Published online: 18 April 2018

(C) The Author(s) 2018

\begin{abstract}
The effect of 2 mass\% rare earth elements (RE) as in mischmetal state on the structure, thermal behaviour and mechanical properties of $\mathrm{Mg}-x \mathrm{Li}-4 \mathrm{Al}(x=4,8$ and 12 by mass percentage). The thermo-derivative analysis was implemented using the UMSA platform (Universal Metallurgical Simulator and Analyzer) with cooling rate approx. $\approx 0.6{ }^{\circ} \mathrm{C} \mathrm{s}^{-1}$ that correspond to natural cooling. Microstructural evaluations were identified by $\mathrm{X}$-ray diffraction, scanning electron microscopy, light microscope and energy-dispersive X-ray spectroscopy. Obtained results from the thermal derivative analysis allowed determining the solidification pathways for $\mathrm{Mg}-\mathrm{Li}-\mathrm{Al}-\mathrm{RE}$ alloy. The addition of grain refinement causes changes in crystallisation process. The addition of RE elements affected an enhancement in mechanical properties, which was associated with the development of intermetallic compounds; the maximum increases in hardness at level $240 \%$ was observed for single $\alpha$-phase alloy and at level $19 \%$ for $\alpha+\beta$ alloy.
\end{abstract}

Keywords $\mathrm{Mg}-\mathrm{Li} \cdot$ Grain refinement $\cdot$ Rare earth $\cdot$ Metal solidification $\cdot$ Microstructure

\section{Introduction}

As unique structural materials, $\mathrm{Mg}-\mathrm{Li}$ alloys have become hopeful materials for various utilisations in the areas of aerospace and military engineering because of their attributes, such as super lightweight, relatively high specific strength and stiffness, and good formability. Magnesiumlithium alloys have an unusually low density $\left(1.35-1.65 \mathrm{~g} \mathrm{~cm}^{-3}\right)$ and superior formability as a consequence of the addition of lithium to magnesium. Alloying magnesium with lithium can also modify the crystal structure of magnesium. Magnesium-lithium alloys are commonly classified into three classes, according to the lithium content [1-4]. When the lithium content is below

Mariusz Król

mariusz.krol@polsl.pl

1 Institute of Engineering Materials and Biomaterials, Faculty of Mechanical Engineering, Silesian University of Technology, Konarskiego 18a St., 44-100 Gliwice, Poland

2 Institute of Metals Technology, Faculty of Materials Engineering and Metallurgy, Silesian University of Technology, Katowice, Poland

3 Institute of Materials Science, Faculty of Materials Engineering and Metallurgy, Silesian University of Technology, Katowice, Poland
5.7 mass $\%$, the alloy is composed of the $\alpha$ phase, with a hexagonal close-packed crystal structure and is a solid solution of lithium in magnesium. Those alloys show a moderate strength and a low formability because of the basal slip domination. With a lithium content between 5.7 and 10.3 mass $\%$, the structure is composed of a duplex structure, i.e. the $\alpha$ phase and $\beta$ phase. The ductility is much improved with a higher level of lithium additions, but the strength is then notably lowered. Increasing $\mathrm{Li}$ content in magnesium alloys leads to an interesting compromise since it combines the average strength of the $\alpha$ phase including the high ductility of the $\beta$ phase. The alloy including a lithium content above 10.3 mass\% is composed of the $\beta$ phase, which possesses a body-centred cubic crystal structure and is a solid solution of magnesium in lithium [5-7].

The magnesium-lithium alloys can also be strengthened by adding strengthening agents, such as rare earth elements and/or other alloying elements. Aluminium is one of the most common alloying components in $\mathrm{Mg}-\mathrm{Li}$ base alloys. The aluminium added in $\mathrm{Mg}-\mathrm{Li}$ alloys principally dissolves in solid solutions. When the $\mathrm{Al}$ content is higher than 3 mass\%, AlLi compound forms in the alloys. The addition of $\mathrm{Al}$ in $\mathrm{Mg}-\mathrm{Li}$ alloys leads to the improvement of strength and the slight increase in density, but it causes the 
reduction of elongation. When the addition is higher than 6 mass \%, the deterioration of elongation is severe [8-10].

Alloying magnesium with rare earth elements is used to develop light construction alloys for the applications at elevated and high temperatures and improve corrosion resistance and improve creep resistance. Generally, RE elements in $\mathrm{Mg}$ have relatively high solubility decreasing significantly with decreasing temperature. Rare earth components are typically useful metallic elements, which can improve the binding energy of magnesium atoms, and decrease the diffusion velocity of atoms. RE elements can efficiently enhance the heat resistance of $\mathrm{Mg}$ alloy because they can develop the high-melting-point compounds including other elements and refine the grains. Many RE components manifested satisfying grain refinement effect in magnesium alloys in a cast state. Supplement of $\mathrm{La}, \mathrm{Pr}$ and $\mathrm{Ce}$ to $\mathrm{Al}$ containing $\mathrm{Mg}$ resulted in significant grain refinement. Ali et al. [4] estimated that restriction of grains growth of separated RE elements in front of growing liquid/solid interface is the principal purpose of the grain refinement. That hypothesis was based on the research of RE-containing intermetallic phases on the grain boundaries of the cast alloy [11-18].

Thermal analysis (TA) is a significant method for research to investigate the solidification characteristics of the alloy. One of the thermal analyses is a thermal derivative analysis that gives information about crystallisation sequence. Also, analysis of the cooling curve provides metallurgists to follow the actions of particular intermetallic phase transforms due to the additions. Microstructure analysis with simultaneous thermal analysis can give information about solidification pathways for $\mathrm{Mg}-$ Li-Al-RE alloy [2, 11, 13, 15, 19-21].

In this study, the binary alloys $\mathrm{Mg}-x \operatorname{Li}(x=4,8$ and 12 by mass percentage) and $\mathrm{Mg}-x \mathrm{Li}$ with 4 mass $\% \mathrm{Al}$ and 2 mass\%RE were manufactured by processed by commercial RE elements. The microstructure evolution, thermal derivative analysis, dilatation, scanning electron microscopy, X-ray diffraction, and energy-dispersive X-ray spectroscopy methods were used to examine the effect of $\mathrm{RE}$ elements on $\mathrm{Mg}-\mathrm{Li}-\mathrm{Al}$ alloys. The influence of $\mathrm{Al}$ and RE elements on hardness was also analysed.

\section{Experimental}

The $\alpha, \alpha+\beta$ and $\beta$ alloys (Fig. 1), i.e. $\mathrm{Mg}-4.5 \mathrm{Li}, \mathrm{Mg}-$ $4 \mathrm{Li}-4 \mathrm{Al}+2 \mathrm{RE}, \quad \mathrm{Mg}-9 \mathrm{Li}, \quad \mathrm{Mg}-8 \mathrm{Li}-4 \mathrm{Al}+2 \mathrm{RE}, \quad \mathrm{Mg}-$ $12 \mathrm{Li}, \mathrm{Mg}-12 \mathrm{Li}-4 \mathrm{Al}+2 \mathrm{RE}$ used in the experiment were smelted with $\mathrm{CP}$ (commercial pure) magnesium, CP lithium, $\mathrm{CP}$ aluminium, the $\mathrm{Ce}-\mathrm{La}-\mathrm{Nd}$ mischmetal of RE, under the protection of argon environment in an induction furnace. Pure rare earth is much expensive than mischmetal

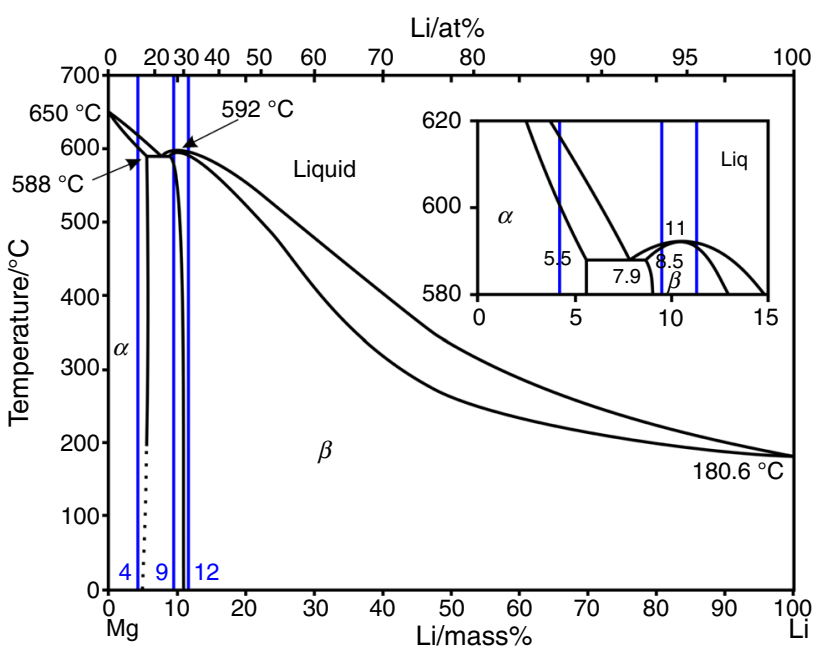

Fig. 1 The binary phase diagram of $\mathrm{Mg}-\mathrm{Li}$ system

(RE). The alloying with mischmetal in $\mathrm{Mg}-\mathrm{Li}$ base alloys has more industrial value. Melting temperature was approx. $700-720{ }^{\circ} \mathrm{C}$ and the melting time approx. five min., taking into account the high bath stirring electrodynamic eddy currents enough for the complete homogenisation of the

Table 1 Chemical composition of analysed alloys

\begin{tabular}{lllll}
\hline Alloy & \multicolumn{4}{l}{ Chemical composition/mass\% } \\
\cline { 2 - 5 } & $\mathrm{Mg}$ & $\mathrm{Li}$ & $\mathrm{Al}$ & $\mathrm{RE}$ \\
\hline $\mathrm{Mg}-4.5 \mathrm{Li}$ & Balance & 4.5 & - & \\
$\mathrm{Mg}-9 \mathrm{Li}$ & Balance & 9 & - & \\
$\mathrm{Mg}-12 \mathrm{Li}$ & Balance & 12 & - & \\
$\mathrm{Mg}-4 \mathrm{Li}-4 \mathrm{Al}+2 \mathrm{RE}$ & Balance & 4 & 4 & 2 \\
$\mathrm{Mg}-8 \mathrm{Li}-4 \mathrm{Al}+2 \mathrm{RE}$ & Balance & 8 & 4 & 2 \\
$\mathrm{Mg}-12 \mathrm{Li}-4 \mathrm{Al}+2 \mathrm{RE}$ & Balance & 12 & 4 & 2 \\
\hline
\end{tabular}

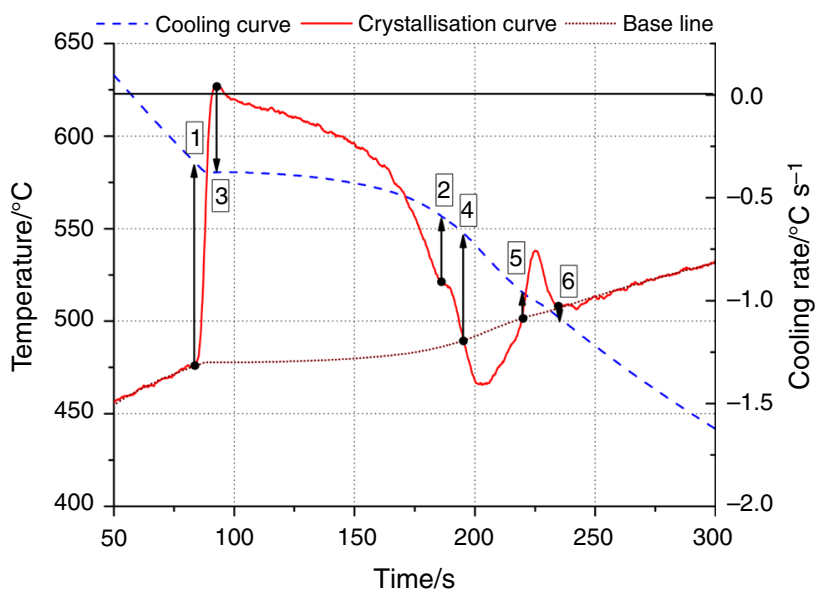

Fig. 2 Cooling and crystallisation curve, base line and representation of characteristic parameters registered during thermal analysis 
Table 2 Solidification characteristic parameters shown in Fig. 2

\begin{tabular}{|c|c|c|}
\hline Point & Symbol & Characteristic \\
\hline 1 & $T_{\mathrm{N}}$ & $\begin{array}{l}\alpha \text {-Mg nucleation temperature (liquidus } \\
\text { temperature) }\end{array}$ \\
\hline 2 & $T_{\alpha^{\prime}, \mathrm{G}}$ & $\alpha^{\prime}-\mathrm{Mg}$ growth temperature \\
\hline 3 & $T_{\beta, \mathrm{G}}$ & $\beta$-Li growth temperature \\
\hline 4 & $T_{\mathrm{SOL}}$ & Solidus temperature \\
\hline 5 & $T_{\alpha \text { "s }}$ & $\alpha$ '”-Mg growth temperature, start \\
\hline 6 & $T_{\alpha \text {,f }}$ & $\alpha$ '’-Mg growth temperature, finish \\
\hline 7 & $\mathrm{Mg}_{17} \mathrm{Al}_{12 \mathrm{~N}}$ & Nucleation of $\mathrm{Mg}_{17} \mathrm{Al}_{12}$ phase \\
\hline 8 & $\mathrm{Mg}_{17} \mathrm{Al}_{12 \mathrm{~F}}$ & End of $\mathrm{Mg}_{17} \mathrm{Al}_{12}$ phase participate \\
\hline
\end{tabular}

melt. Grain refinement was introduced at the end of the melting process from the vacuum containers. After placing the grain refinements in the alloy, the liquid metal was kept in a liquid state for two minutes and then cast. Melts are held in a crucible of $\mathrm{Al}_{2} \mathrm{O}_{3}$ in shape of $\varnothing 60 \times 80 \mathrm{~mm}$, using the ceramic material sheath thermocouple for measuring the temperature of melting and casting alloys. The chemical composition of the cast alloys is listed in Table 1 .

The thermal derivative analysis (TDA) was done on the prepared cylindrical samples in shape of $20 \mathrm{~mm}$ in diameter and $30 \mathrm{~mm}$ in height using UMSA device. Samples were melted at $700{ }^{\circ} \mathrm{C}$ in an argon atmosphere. Following isothermal holding for $90 \mathrm{~s}$, all the melts were solidified and cooled to ambient temperature in the crucibles with argon protection in the furnace to minimise the oxidation. The signal from a high-sensitivity K-type was acquired using a high-speed National Instruments data acquisition system. The recorded data were analysed in Fityk software. The cooling curves and corresponding first derivative curve were plotted to enhance slope changes which were related to the solidification reactions for different phases and to facilitate the determination of the critical solidification characteristics of the alloys. The test samples were solidified at a cooling rate of approximately $0.6^{\circ} \mathrm{Cs}^{-1}$ that was equivalent to the solidification process under natural cooling. The baseline has been predicted by 6 th polynomial fitting $(\mathrm{d} T / \mathrm{d} t)_{\mathrm{BL}}=$ $a_{0}+a_{1} T+a_{2} T^{2}+a_{3} T^{3}+a_{4} T^{4}+a_{5} T^{5}+a_{6} T^{6}$ between the beginning and the end of solidification in the first derivative curve. The sixth-order polynomial yields a correlation coefficient higher than 0.97 . Details of the thermal analysis and solidification parameters are shown in Fig. 2 and Table 2.

Every microstructure study samples were separated from the section closest to the thermocouple and fabricated using standard grinding and polishing procedures recommended by Struers before final etching. Microstructural investigation of the alloys studied was carried out using scanning electron microscopy (SEM) and light microscopy. Interpretation of intermetallic compounds was performed through energy-dispersive X-ray spectroscopy (EDS). Phase identification was achieved by electron back-scatter diffraction (EBSD). The phases were identified by X-ray diffractometry using a monochromatic Co $\mathrm{K} \alpha$ radiation. The microstructural images were recorded with the use of

(a)

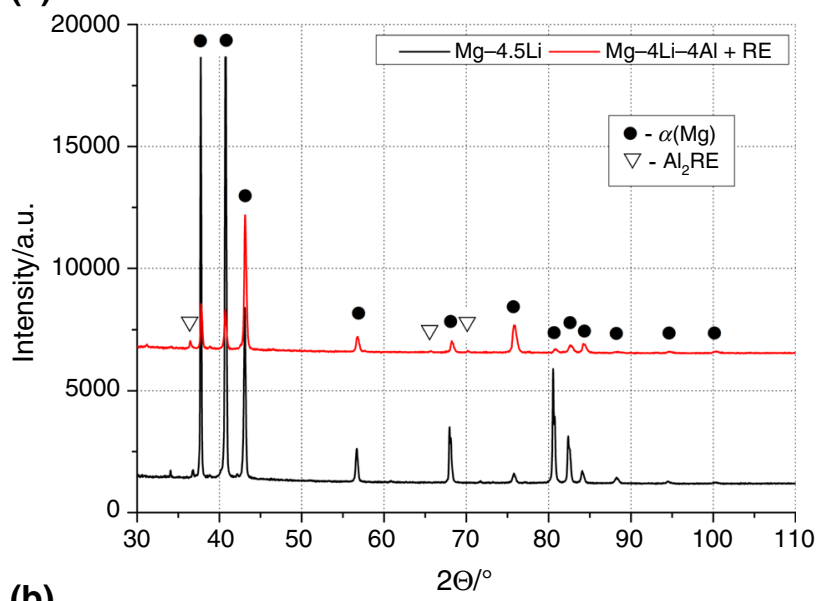

(b)

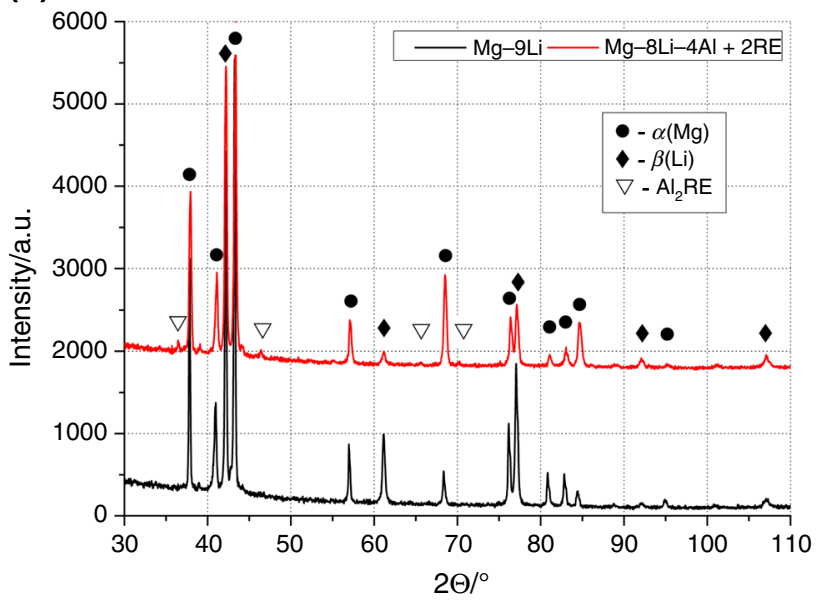

(c)

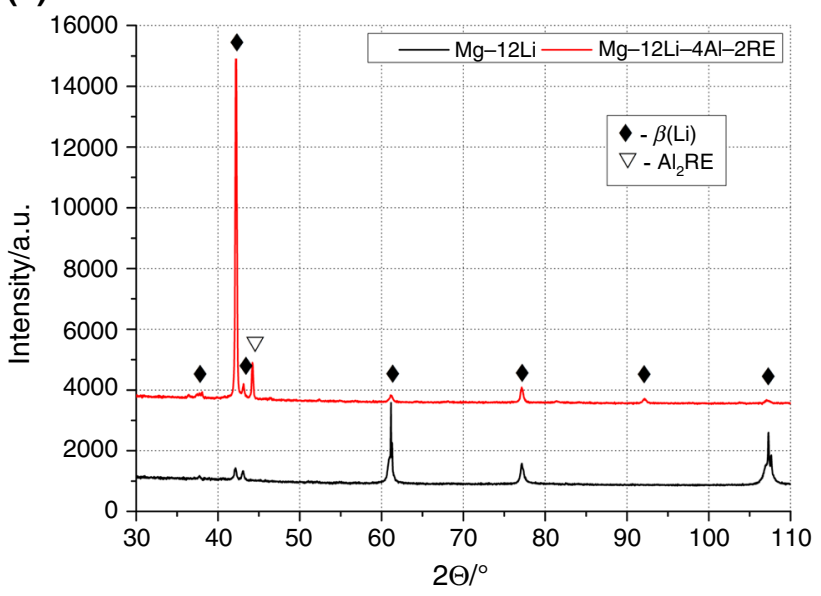

Fig. 3 XRD patterns of: $\mathrm{a} \mathrm{Mg}-4.5 \mathrm{Li}$ and $\mathrm{Mg}-4 \mathrm{Li}-4 \mathrm{Al}+2 \mathrm{RE}$, b $\mathrm{Mg}-9 \mathrm{Li}$ and $\mathrm{Mg}-8 \mathrm{Li}-4 \mathrm{Al}+2 \mathrm{RE}$, c $\mathrm{Mg}-12 \mathrm{Li}$ and $\mathrm{Mg}-12 \mathrm{Li}-$ $4 \mathrm{Al}+2 \mathrm{RE}$ 

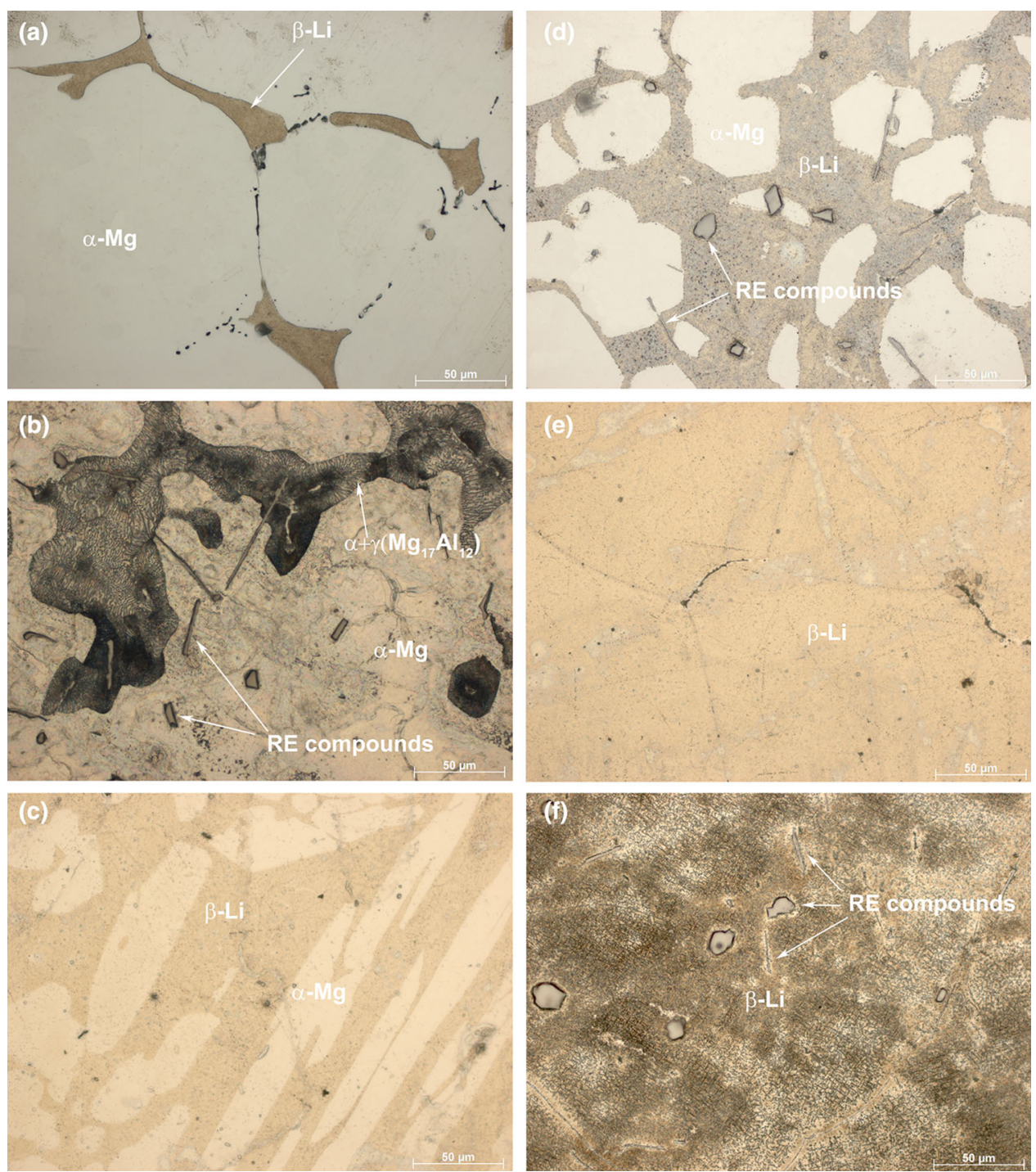

Fig. 4 Optical microstructure of as-cast and after modification of: a $\mathrm{Mg}-4.5 \mathrm{Li}, \mathbf{b} \mathrm{Mg}-4 \mathrm{Li}-4 \mathrm{Al}+2 \mathrm{RE}, \mathbf{c} \mathrm{Mg}-9 \mathrm{Li}, \mathbf{d ~ M g}-8 \mathrm{Li}-4 \mathrm{Al}+2 \mathrm{RE}$, e $\mathrm{Mg}-12 \mathrm{Li}, \mathbf{f ~ M g}-12 \mathrm{Li}-4 \mathrm{Al}+2 \mathrm{RE}$

the Leica equipped Q-WinTM image analyser using a polarised light technique. Hardness tests were made using Zwick ZHR 4150 TK hardness tester in the HRF scale.

\section{Results and discussion}

Figure 3 shows the X-ray diffraction (XRD) patterns of the six analysed $\mathrm{Mg}-\mathrm{Li}$ alloys. The alloys containing 4 mass\% lithium consisted of the single $\alpha(\mathrm{Mg})$ phase (solid solution of lithium in hexagonal close-packed (hcp) magnesium lattice). For the alloys with 8 mass $\%$ lithium, a dual structure $(\alpha+\beta)$ was identified. With the addition of both aluminium and rare earth elements, an $\mathrm{Al}_{2} \mathrm{RE}$ intermetallic compound could be detected. The $\mathrm{Al}_{2} \mathrm{RE}$ phase was one of the main structural constituents for experimental alloys containing $\mathrm{RE}$ elements. The $\mathrm{Al}_{2} \mathrm{RE}$ intermetallic compound was identified from the $\mathrm{Al}_{2} \mathrm{Ce}$ phase, $\mathrm{Fd}-3 \mathrm{~m}$ space group, $a=b=c=8.0900 \mathrm{~nm}$. It must be noted that the volume fraction of $\gamma-\mathrm{Mg}_{17} \mathrm{Al}_{12}$ phase (as observed in microstructure presented in Fig. 4b) is too low to be detected in the X-ray analysis. The XRD profile of unmodified 12 mass\%Li alloy demonstrates that it consists of one phase- $\beta(\mathrm{Li})$ phase (matrix phase, a solid solution of magnesium in body-centred cubic (bcc) lithium lattice). The achieved XRD results are faithful to the observation using a light and scanning electron microscopes (Figs. 4, 5).

Figure 4 displays the optical micrographs of the six analysed $\mathrm{Mg}-\mathrm{Li}$ alloys. It clearly shows that (Fig. 4c) the alloys with 9 mass\% lithium were composed of a duplex $(\alpha+\beta)$ microstructure, while the other alloys (Fig. 4 a, e) consisted of the single $\alpha(\mathrm{Mg})$ and $\beta(\mathrm{Li})$ phase, respectively, in agreement with the results of the XRD analysis shown in Fig. 3; (Fig. 4c) grains were coarsened as a result of 


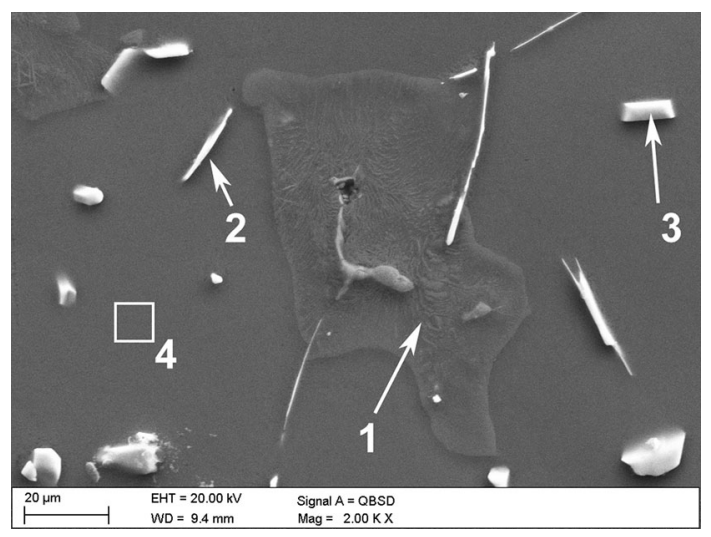

Fig. 5 Microstructure of the $\mathrm{Mg}-4 \mathrm{Li}-4 \mathrm{Al}+2 \mathrm{RE}$. The points marked by arrows indicate where the microanalyses were taken. The chemical composition is as follow (\%at.): point $1-61.4 \mathrm{Mg}-38.5 \mathrm{Al}$, point 27.4 Mg-59.1Al-9.9La-3.1Ce, point $3-4.7 \mathrm{Mg}-65.1 \mathrm{Al}-6.3 \mathrm{La}-$ 24.9Ce, point $4-95.6 \mathrm{Mg}-4.4 \mathrm{Al}$

alloying with lithium but became refined with the addition of rare earth elements (Fig. 4d). Additionally, intermetallic compounds with a blocky and needle shape were present in the matrix (Fig. 4b, d, e). Moreover, in analysed $\mathrm{Mg}-4 \mathrm{Li}-$ 4Al alloy after modification of 2 mass\% of RE in the grain boundary areas, eutectic $\alpha+\gamma$ and $\mathrm{Mg}_{17} \mathrm{Al}_{12}$ phase was observed, which is consistent with the $\mathrm{Mg}-\mathrm{Al}$ binary system [19]. Rare earth element and aluminium appear to be concentrated in small and angular structures dispersed both in $\alpha$-phase and $\beta$-phase (Figs. 4, 5).

Figure 5 presents an image of the investigated alloy microstructure at high magnification. The detailed distribution of the alloying elements in particular structure constituents was analysed by using a SEM instrument. A further SEM observation indicates a divorced eutectic characteristic $\alpha+\gamma\left(\mathrm{Mg}_{17} \mathrm{Al}_{12}\right)$ based on analysis of chemical composition in microregions, as can be seen from Fig. 5 (mark 1). Moreover, SEM analysis reveals that the microstructure contains acicular compounds RE-rich mischmetal, while irregular shaped Ce-rich phases (marks 2 and 3 , respectively).

Through the XRD results and the atomic ratio of EDS results, it can be determined that the dot compounds are the $\mathrm{Al}_{2} \mathrm{Ce}$ phase which was positively identified with XRD method (Fig. 3). The aluminium content (mark 4,) in solid solution $\alpha-\mathrm{Mg}$ is higher than its maximal solubility at ambient temperature [22]. Moreover, analysis of $\mathrm{Mg}-8 \mathrm{Li}-$ $4 \mathrm{Li}+2 \mathrm{RE}$ alloys showed that rare earth elements and aluminium appear to be concentrated in small and angular compounds in both in $\alpha$-phase and $\beta$-phase.

The intermetallic compounds also exist in the $\beta$-Li phase (analysis of $\mathrm{Mg}-12 \mathrm{Li}-4 \mathrm{Al}+2 \mathrm{RE}$ ), with the addition of RE elements. From the EDS analysis, it can be known that the dot compounds are La-rich and Al-rich phases and fishbone-shaped compounds are La-rich, Ce-rich and Alrich phases.

Figure 6 represents cooling curves of cast $\mathrm{Mg}-\mathrm{Li}$ alloys at a different content of Li before and after the modification by RE elements. Main solidification events obtained during thermal analysis are listed in Table 3. The temperatures main reactions are identified. However, the exothermic reaction of Al-RE compounds is too low to be detected in the cooling or derivatives curves and must be noted that the melting temperatures of $\mathrm{Al}-\mathrm{RE}$ elements are above than those in presented experiment (i.e. $\mathrm{Al}_{2} \mathrm{Ce} \approx 1480^{\circ} \mathrm{C}$ ).

Analysis of the results from thermal derivative analysis of $\mathrm{Mg}-4.5 \mathrm{Li}$ and $\mathrm{Mg}-4 \mathrm{Li}-4 \mathrm{Al}+2 \mathrm{RE}$ alloys shows that solidification process of $\mathrm{Mg}$ alloys starts with the nucleation of $\alpha^{\prime}(\mathrm{Mg})$ phase at 611.2 and $617.9^{\circ} \mathrm{C}$, respectively. Next thermal event registered on crystallisation curve is $\alpha^{\prime}(\mathrm{Mg})$ growth temperature. Addition of RE elements causes a decrease in $\alpha^{\prime}(\mathrm{Mg})$ growth temperature from 607.6 to $593.1^{\circ} \mathrm{C}$. End of solidification of analysed $\mathrm{Mg}-$ 4.5 Li alloy before and after the modification finish at 571.4 and $506.1{ }^{\circ} \mathrm{C}$, respectively. It must be noted that analysis of unmodified alloy is characterised by one more thermal event (Fig. 6a, point 3 ) that corresponds to growth of $\beta(\mathrm{Li})$ $\left(583.3^{\circ} \mathrm{C}\right)$, which has been confirmed by studies of the microstructure, i.e. $\beta$ (Li)-phase segregation within the grain boundaries (Fig. 4a). Moreover, modification by RE elements, i.e. addition of $\mathrm{Al}$ content to $\mathrm{Mg}-4.5 \mathrm{Li}$ alloy causes appearance in microstructure (according to the $\mathrm{Mg}-$ $\mathrm{Al}$ binary system) a $\gamma-\mathrm{Mg}_{17} \mathrm{Al}_{12}$ phase. The thermal event, i.e. temporary evolves the latent heat, thereby decreasing cooling rate apparently visible on first derivative (Fig. 6b, point 7 and 8) and confirmed by microstructure analysis (Fig. 4b). The beginning of crystallisation of $\mathrm{Mg}_{17} \mathrm{Al}_{12}$ phase was observed at $423.5^{\circ} \mathrm{C}$ and finished at $401.4^{\circ} \mathrm{C}$.

The crystallisation pathway of $\mathrm{Mg}-4.5 \mathrm{Li}$ before and after the modification, based on thermal derivative analysis, is proposed in Table 4.

Figure $6 \mathrm{c}$ and $\mathrm{d}$ represents a thermal derivative analysis of $\mathrm{Mg}-9 \mathrm{Li}$ alloy before and after modification by RE elements. Nucleation of $\beta$ (Li) phase starts at 586.7 and $572.9^{\circ} \mathrm{C}$, respectively. Generally, for an alloy with 9 mass\% of $\mathrm{Li}$, an addition of $\mathrm{RE}$ elements causes a decrease in nucleation of $\beta(\mathrm{Li})$ phase, growth temperature and solidus temperature, i.e. from 586.7 to $572.9^{\circ} \mathrm{C}$, from 580.4 to $567.2^{\circ} \mathrm{C}$ and from 547.8 to $493.3^{\circ} \mathrm{C}$ respectively. For analysed alloy, an addition of RE has no influence, in this case, on $\alpha^{\prime}(\mathrm{Mg})$ growth reaction, which is approx. $557^{\circ} \mathrm{C}$. Furthermore, Fig. $6 \mathrm{c}$ represents one more exothermic peak, which was not registered during thermal analysis of $\mathrm{Mg}-8 \mathrm{Li}-4 \mathrm{Al}+2 \mathrm{RE}$ alloy. Points 5 and 6 correspond to the transition in solid state $\beta(\mathrm{Li}) \rightarrow \beta(\mathrm{Li})+\alpha^{\prime \prime}(\mathrm{Mg})$, according to the solvus line in the binary system of $\mathrm{Mg}-\mathrm{Li}$ (Fig. 1). This reaction starts at $515.7^{\circ} \mathrm{C}$ and finishes at 

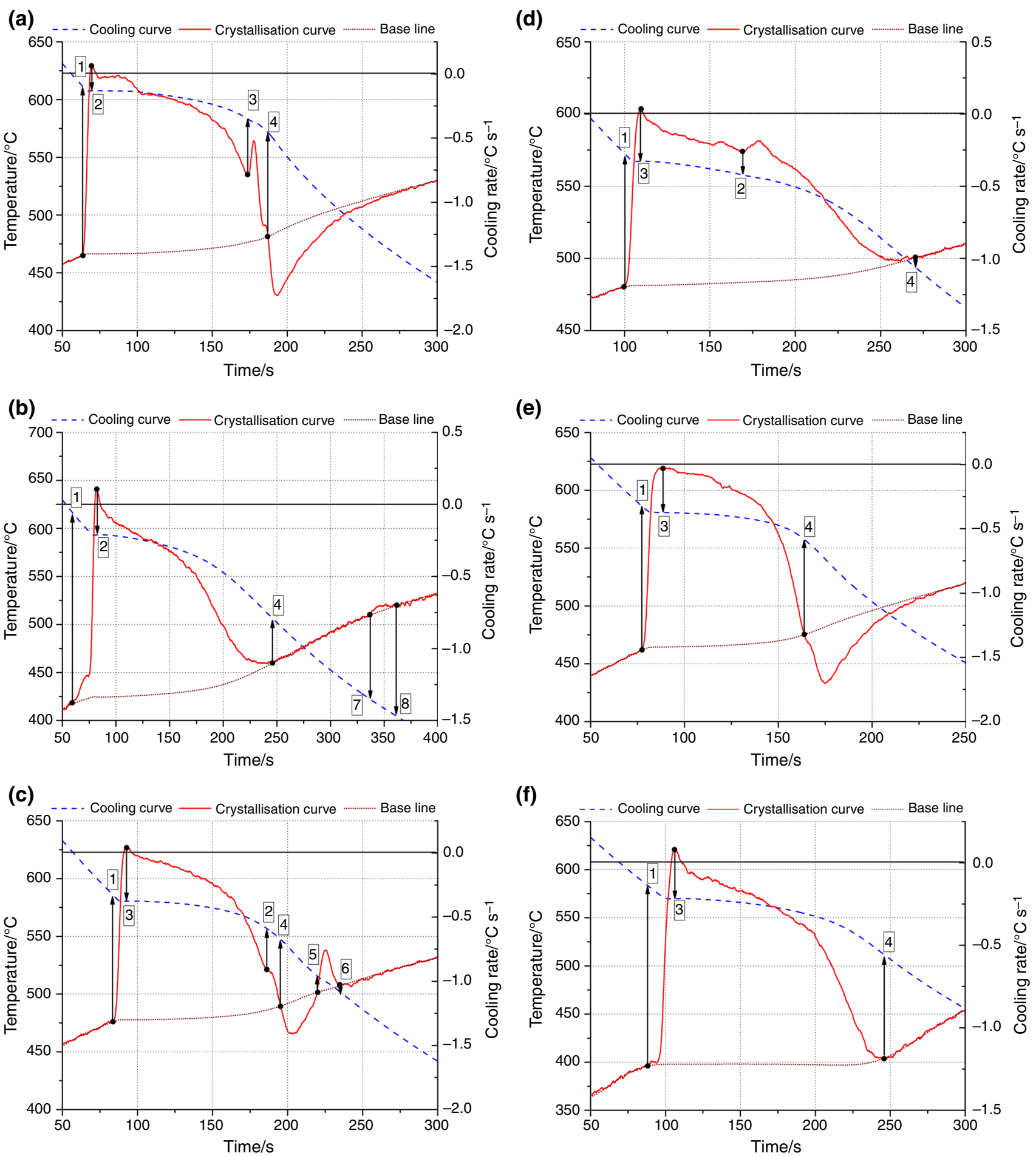

Fig. 6 Thermal derivative analysis of: a $\mathrm{Mg}-4.5 \mathrm{Li}, \mathbf{b} \mathrm{Mg}-4 \mathrm{Li}-4 \mathrm{Al}+2 \mathrm{RE}, \mathbf{c} \mathrm{Mg}-9 \mathrm{Li}, \mathbf{d} \mathrm{Mg}-8 \mathrm{Li}-4 \mathrm{Al}+2 \mathrm{RE}, \mathbf{e ~} \mathrm{Mg}-12 \mathrm{Li}$, f $\mathrm{Mg}-12 \mathrm{Li}-$ $4 \mathrm{Al}+2 \mathrm{RE}$

$503.1^{\circ} \mathrm{C}$. Analysis of $\mathrm{Mg}-8 \mathrm{Li}-4 \mathrm{Al}+2 \mathrm{RE}$ alloy and its crystallisation sequence can be summarised as an addition of $\mathrm{RE}$ elements causes a reduction of the $\alpha+\beta$ area below of $588^{\circ} \mathrm{C}$ to lower concentrations of $\mathrm{Li}$ (Table 5).

Thermal derivative analysis of $\mathrm{Mg}-12 \mathrm{Li}$ and $\mathrm{Mg}-12 \mathrm{Li}-$ $4 \mathrm{Al}+2 \mathrm{RE}$ alloys shows that for both analysed alloys $\beta(\mathrm{Li})$ nucleation temperature $T_{\mathrm{N}}$ is approx. $585^{\circ} \mathrm{C}$. Addition of rare elements to $\mathrm{Mg}-12 \mathrm{Li}$ alloy causes a decrease in $T_{\beta, \mathrm{G}}$ from 580.7 to $569.7^{\circ} \mathrm{C}$. Moreover, modification causes decrease in solidification temperature range, i.e. decreases a solidus temperature $T_{\mathrm{SOL}}$ from 557.7 to $511.9^{\circ} \mathrm{C}$. Generally, for all analysed $\mathrm{Mg}-\mathrm{Li}$ alloys, modification causes increase in the 
Table 3 Solidification characteristics of parameters determined during crystallisation of $\mathrm{Mg}-\mathrm{Li}$ alloys

\begin{tabular}{lllllll}
\hline Reaction & $\mathrm{Mg}-4.5 \mathrm{Li}$ & $\mathrm{Mg}-4 \mathrm{Li}-4 \mathrm{Al}+2 \mathrm{RE}$ & $\mathrm{Mg}-9 \mathrm{Li}$ & $\mathrm{Mg}-8 \mathrm{Li}-4 \mathrm{Al}+2 \mathrm{RE}$ & $\mathrm{Mg}-12 \mathrm{Li}$ & $\mathrm{Mg}-12 \mathrm{Li}-4 \mathrm{Al}+2 \mathrm{RE}$ \\
\hline $1 / T_{\mathrm{N}} /{ }^{\circ} \mathrm{C}$ & 611.2 & 617.9 & 586.7 & 572.9 & 585.1 & 584.9 \\
$2 / T_{\alpha, \mathrm{G}} /{ }^{\circ} \mathrm{C}$ & 607.6 & 593.1 & 556.5 & 557.7 & - & - \\
$3 / T_{\beta, \mathrm{G}} /{ }^{\circ} \mathrm{C}$ & 583.3 & - & 580.4 & 567.2 & 580.7 & 569.7 \\
$4 / T_{\mathrm{SOL}} /{ }^{\circ} \mathrm{C}$ & 571.4 & 506.1 & 547.8 & 493.3 & 511.9 \\
$5 / T_{\alpha,}{ }^{\prime} \mathrm{s} /{ }^{\circ} \mathrm{C}$ & - & - & 515.7 & - & - & - \\
$6 / T_{\alpha,{ }^{\prime} \mathrm{f}} / \mathrm{C}$ & - & - & 503.1 & - & - & - \\
$7 / \mathrm{Mg}_{17} \mathrm{Al}_{12 \mathrm{~N}} /{ }^{\circ} \mathrm{C}$ & - & 423.5 & - & - & - & - \\
$8 / \mathrm{Mg}_{17} \mathrm{Al}_{12 F} /{ }^{\circ} \mathrm{C}$ & - & 401.4 & - & - & \\
\hline
\end{tabular}

Table 4 The crystallisation pathway of magnesium alloy with 4 mass\% of $\mathrm{Li}$

Table 5 The crystallisation pathway of magnesium alloy with 8 and 9 mass\% of $\mathrm{Li}$

Fig. 7 Effect of RE addition on the hardness of analysed $\mathrm{Mg}-\mathrm{Li}$ alloys

\begin{tabular}{lll}
\hline Reaction & $\mathrm{Mg}-4.5 \mathrm{Li}$ alloy & $\mathrm{Mg}-4 \mathrm{Li}-4 \mathrm{Al}+2 \mathrm{RE}$ alloy \\
\hline 1. & $\mathrm{L} \rightarrow \alpha^{\prime}(\mathrm{Mg})$ & $\mathrm{L} \rightarrow \alpha^{\prime}(\mathrm{Mg})$ \\
2. & Maximum growth of primary $\alpha^{\prime}(\mathrm{Mg})$-phase & Maximum growth of primary $\alpha^{\prime}(\mathrm{Mg})$-phase \\
3. & $\alpha^{\prime}\left(\mathrm{Mg} \rightarrow \alpha^{\prime}(\mathrm{Mg})+\beta(\mathrm{Li})\right.$ & - \\
4. & - & $\alpha^{\prime}(\mathrm{Mg}) \rightarrow \alpha^{\prime}(\mathrm{Mg})+\gamma\left(\mathrm{Mg}_{17} \mathrm{Al}_{12}\right)$ \\
\hline
\end{tabular}

\begin{tabular}{lll}
\hline Reaction & Mg-9Li alloy & $\mathrm{Mg}-8 \mathrm{Li}-4 \mathrm{Al}+2 \mathrm{RE}$ alloy \\
\hline 1. & $\mathrm{L} \rightarrow \beta(\mathrm{Li})$ & $\mathrm{L} \rightarrow \beta(\mathrm{Li})$ \\
2. & Maximum growth of primary $\beta(\mathrm{Li})$-phase & Maximum growth of primary $\beta(\mathrm{Li})$-phase \\
3. & $\beta(\mathrm{Li}) \rightarrow \beta(\mathrm{Li})+\alpha^{\prime}(\mathrm{Mg})$ & $\beta(\mathrm{Li}) \rightarrow \beta(\mathrm{Li})+\alpha^{\prime}(\mathrm{Mg})$ \\
4. & $\beta(\mathrm{Li}) \rightarrow \beta(\mathrm{Li})+\alpha^{\prime}{ }^{\prime}(\mathrm{Mg})$ & \\
\hline
\end{tabular}

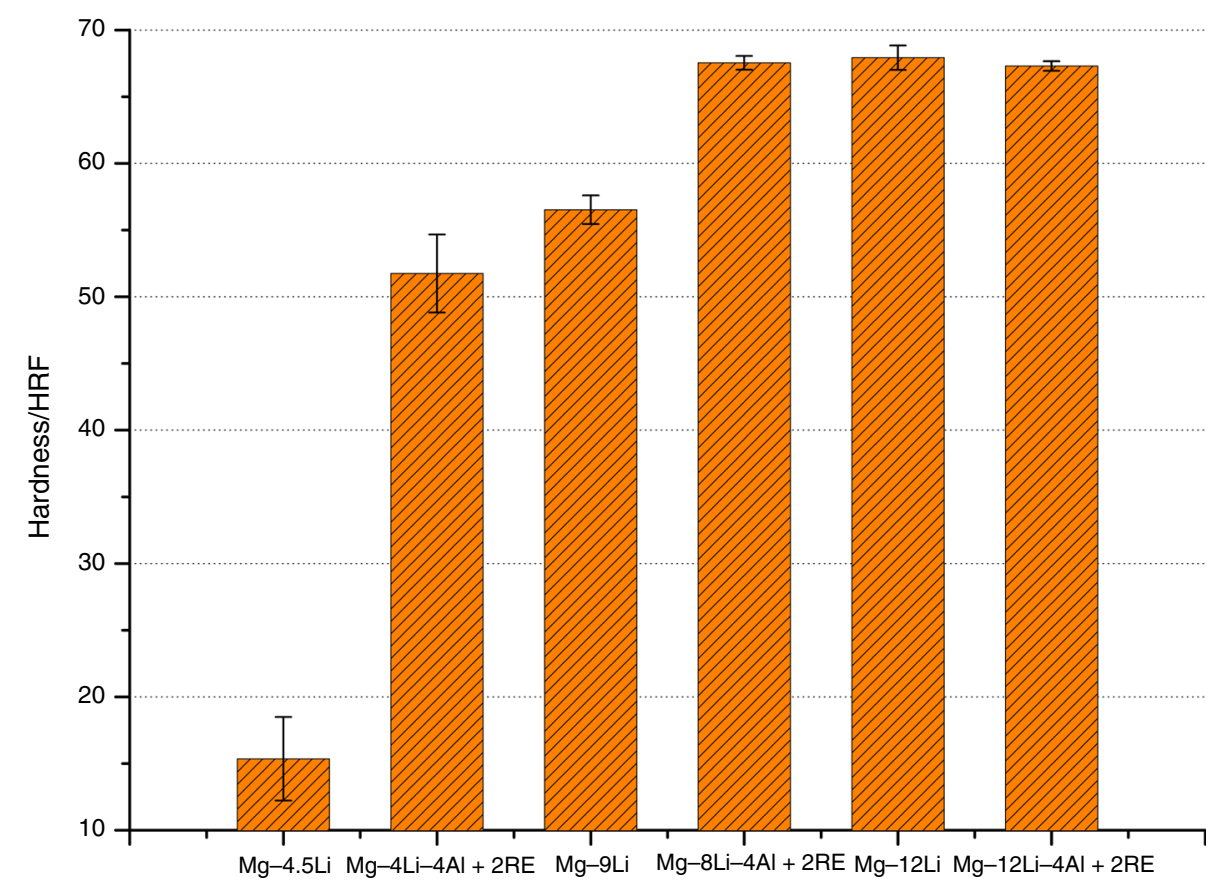


solidification temperature range from approx. 40 to 110,80 and $73^{\circ} \mathrm{C}$.

The addition of RE elements led to an increase in hardness of the analysed Mg-Li alloys (Fig. 7): from 15 for the $\alpha(\mathrm{Mg})$ single-phase alloy to $51 \mathrm{HRF}$ and from $56 \mathrm{HRF}$ to $67 \mathrm{HRF}$ for duplex $\alpha(\mathrm{Mg})+\beta(\mathrm{Li})$. However, addition of 2 mass $\%$ of RE to $\beta$-single-phase alloy has no influence on hardness, i.e. the hardness of unmodified and after grain refinement reached approx. $67 \mathrm{HRF}$. The strengthening of $\mathrm{Mg}-\mathrm{Li}$ alloys is due to the solid solution of the intermediate-sized $\mathrm{RE}$ atoms and second-phase hardening due to the Al-RE intermetallic phases $\left(\mathrm{Al}_{2} \mathrm{RE}, \mathrm{Al}_{11} \mathrm{RE}_{3}\right)$ $[13,15,22]$.

\section{Conclusions}

The effects of the addition of 2 mass $\%$ RE grain refiners on the crystallisation process during solidification of the $\mathrm{Mg}-$ Li alloys such as $T_{\mathrm{N}}, T_{\mathrm{G}}$ and $T_{\mathrm{SOL}}$, microstructure and hardness were studied. The results are summarised as follows:

1. At a $0.6^{\circ} \mathrm{Cs}^{-1}$ cooling rate, the solidification temperature range of analysed $\mathrm{Mg}-\mathrm{Li}$ alloys is increased by adding grain refinement.

2. The addition of RE elements results in the formation of intermetallic compound distributed along the phase boundary as well as across $\alpha$-phase and $\beta$-phase. EDX analysis shows that the precipitated compounds are $\mathrm{Al}_{2} \mathrm{RE}$.

3. Based on hardness measurements it was found that the addition of RE refiners increases hardness.

4. Thermal derivative analysis can be implemented to examine melting and cooling processes of $\mathrm{Mg}-\mathrm{Li}$ alloys and reveal changes in crystallisation process after grain refinement.

Acknowledgements This work was financed by the Ministry of Science and Higher Education of Poland as the statutory financial grant of the Faculty of Mechanical Engineering SUT.

Open Access This article is distributed under the terms of the Creative Commons Attribution 4.0 International License (http://creative commons.org/licenses/by/4.0/), which permits unrestricted use, distribution, and reproduction in any medium, provided you give appropriate credit to the original author(s) and the source, provide a link to the Creative Commons license, and indicate if changes were made.

\section{References}

1. Zhou WR, Zheng YF, Leeflang MA, Zhou J. Mechanical property, biocorrosion and in vitro biocompatibility evaluations of
$\mathrm{Mg}-\mathrm{Li}-(\mathrm{Al})-(\mathrm{RE})$ alloys for future cardiovascular stent application. Acta Biomater. 2013;9(10):8488-98.

2. Sheggaf ZM, Ahmad R, Asmael MBA, Elaswad AMM. Solidification, microstructure, and mechanical properties of the as-cast ZRE1 magnesium alloy with different praseodymium contents. Int J Miner Metall Mater. 2017;24(11):1306-20.

3. Wu R, Yan Y, Wang G, Murr LE, Han W, Zhang Z, Zhang M. Recent progress in magnesium-lithium alloys. Int Mater Rev. 2015;60(2):65-100.

4. Yahia A, Dong W, Bin J, Fusheng P, Ming-Xing Z. Current research progress in grain refinement of cast magnesium alloys: a review article. J Alloy Compd. 2015;619:639-51.

5. Pang S, Wu G, Liu W, Zhang L, Zhang Y, Conrad H, Ding W. Influence of cooling rate on solidification behavior of sand-cast Mg-10Gd-3Y-0.4Zr alloy. Trans Nonferr Metal Soc. 2014;24:3413-20.

6. Rzychoń T, Dyzia M, Pikos I. Microstructure of WE43 magnesium matrix composite reinforced ceramic particles. Solid State Phenom. 2014;211:101-8.

7. Kierzek A, Adamiec J. Evaluation of susceptibility to hot cracking of magnesium alloy joints in variable stiffness condition. Arch Metall Mater. 2011;56(3):759-67.

8. Adamiec J. The influence of construction factors on the weldability of AZ91E alloy. Arch Metall Mater. 2011;56(3):769-78.

9. Liu T, Wu SD, Li SX, Li PJ. Microstructure evolution of $\mathrm{Mg}-$ $14 \% \mathrm{Li}-1 \% \mathrm{Al}$ alloy during the process of equal channel angular pressing. Mater Sci Eng A-Struct. 2007;460-461:499-503.

10. Friedrich HE, Mordike BL. Magnesium technology metallurgy, design data, applications. Berlin: Springer; 2006.

11. Ahmad R, Sheggaf ZM, Asmael MBA, Hamzah MZ. Effect of rare earth addition on solidification characteristics and microstructure of ZRE1 magnesium cast alloy. Adv Mater Res. 2017;3(3):418-27.

12. Wei G, Peng X, Liu J, Hadadzadeh A, Yang Y, Xie W. Microstructure evolution and mechanical properties of $\mathrm{Mg}-9 \mathrm{Li}-$ $3 \mathrm{Al}-2 \mathrm{Sr}$ alloy in change channel angular pressing. Mater Sci Technol Ser. 2015;31(14):1757-63.

13. Sun W, Shi X, Cinkilic E, Luo AA. Investigation of the nonequilibrium solidification microstructure of a Mg-4Al-2RE (AE42) alloy. J Mater Sci. 2016;51(13):6287-94.

14. Zieliński A, Golański G, Sroka M. Comparing the methods in determining residual life on the basis of creep tests of low-alloy Cr-Mo-V cast steels operated beyond the design service life. Int J Press Vessel Pip. 2017;152:1-6. https://doi.org/10.1016/j.ijpvp. 2017.03.002.

15. Braszczyńska-Malik KN, Przełoyńska E. Microstructure of MgAl-RE-type experimental magnesium alloy gravity cast into sand mould. Arch Foundry Eng. 2016;16(2):115-8.

16. Rzychoń T, Szala J, Kiełbus A. Microstructure, castability, microstructural stability and mechanical properties of ZRE1 magnesium alloy. Arch Metall Mater. 2012;57(1):245-52.

17. Xu T, Peng X, Jiang J, Xie W, Chen Y, Zhang X. Comparative study on the microstructure and mechanical properties of $\mathrm{Mg}-\mathrm{Li}-$ Al based alloys with yttrium and strontium addition. J Wuhan Univ Technol Mater Sci Ed. 2015;30(3):626-30.

18. Zhu T, Sun J, Cui Ch, Wu R, Betsofen S, Leng Z, Zhang J, Zhang $\mathrm{M}$. Influence of $\mathrm{Y}$ and $\mathrm{Nd}$ on microstructure, texture and anisotropy of $\mathrm{Mg}-5 \mathrm{Li}-1 \mathrm{Al}$ alloy. Mater Sci Eng A-Struct. 2014;600:1-7.

19. Król M, Tański T, Matula G, Snopiński P, Tomiczek AE. Analysis of crystallisation process of cast magnesium alloys based on thermal derivative analysis. Arch Metall Mater. 2015;60(4):2993-9. https://doi.org/10.1515/amm-2015-0478. 
20. Król M, Mikuszewski T, Kuc D, Tański T, Hadasik E. Thermal assessment of modified ultra-light magnesium-lithium alloys. Arch Metall Mater. 2017;62(4):2433-40. https://doi.org/10.1515/ amm-2017-0358.

21. Krupiński M, Labisz K, Tański T, Krupińska B, Król M, PolokRubiniec M. Influence of $\mathrm{Mg}$ addition on crystallisation kinetics and structure of the $\mathrm{Zn}-\mathrm{Al}-\mathrm{Cu}$ alloy. Arch Metall Mater. 2016;61(2):785-9. https://doi.org/10.1515/amm-2016-0132.

22. Rzychoń T, Kiełbus A. Effect of rare earth elements on the microstructure of $\mathrm{Mg}-\mathrm{Al}$ alloys. J Achiev Mater Manuf Eng. 2016;17(1):149-52. 